\title{
Current practices of waste management at Universitas Diponegoro campus, Indonesia
}

\author{
Yos Johan Utama ${ }^{1}$, Ambariyanto, A ${ }^{2}$, Syafrudin ${ }^{3}$ and Ganjar Samudro ${ }^{3}$ \\ ${ }^{1}$ The Rector of Diponegoro University, Jl. Prof. Soedarto, SH-Tembalang, Semarang Indonesia \\ ${ }^{2}$ The Vice Rector of Research and Innovation, Diponegoro University, Jl. Prof. Soedarto, SH-Tembalang, Semarang Indonesia \\ ${ }^{3}$ The green metric task force, Diponegoro University, Jl. Prof. Soedarto, SH-Tembalang, Semarang Indonesia.
}

\begin{abstract}
The existence of waste is one of the problems faced by the community, including in the college of higher education. Waste is produced not only from personal consumption, but also from other activities including office operations and research activities in laboratories and other personal activities. This condition is also related to increasing the existing activities on the campus of Universitas Diponegoro UNDIP, resulting in increasing waste. Related to this UNDIP gives serious attention to develop integrated waste management system. It is also related to the desire of UNDIP to be a sustainable university, where the principles of greenmetrics are always applied in the management of the environment. This article provides an overview of the curent practices of waste management at UNDIP's campus.
\end{abstract}

\section{Introduction}

The development of campus environmental management system in universities around the world is currently growing very fast. This is also related to the occurrence of Industrial Revolution 4.0, where technology plays a very important role. Improving services from various aspects becomes an important demand for the campus stakeholders, whether services related to the process of education, research and others [1].

One of the important demands is the service related to the condition of the campus environment. Today's college should be able to provide a good environment in the sense of a healthy and comfortable environment for the learning process in it. Campus is no longer a place to learn, but also serves for recreational areas such as sports and arts activities. Therefore, the management of the campus environment becomes very important in the management of universities in general.

Universitas Diponegoro is one of the largest state universities in Indonesia is located in coastal city Semarang. The university main scientific interest is coastal region eco-development [2]. With the main campus in Tembalang, Semarang (other campus in Pleburan, Semarang and in Teluk awur, Jepara), UNDIP is very concern in regard to environmental management. One of our important policies is to provide a comfortable, safe and healthy campus environment for all academic community who carry out various activities on the campus of UNDIP. This article provides an overview of waste management practices conducted at UNDIP Campus, in Tembalang, Semarang, Central Java province.

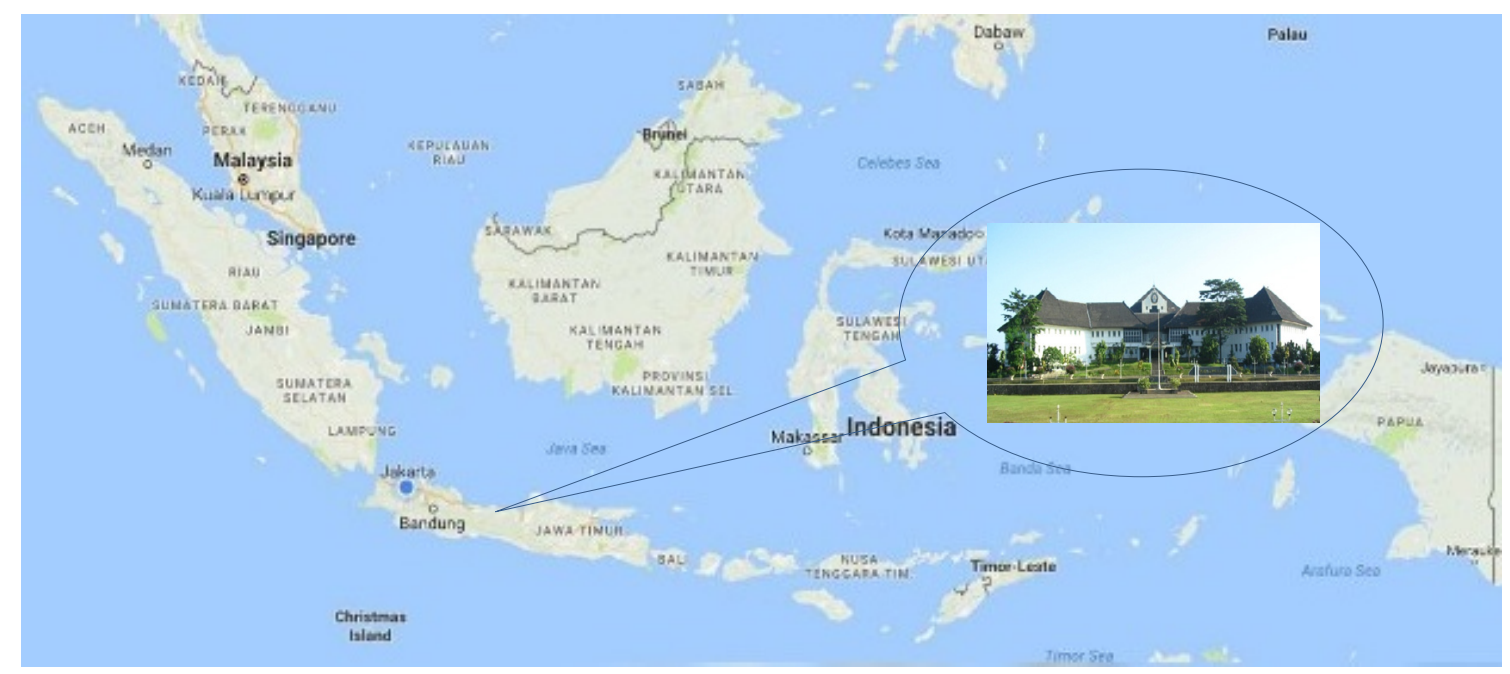

Fig. 1. The location of Universitas Diponegoro at Central Java, Indonesia

\footnotetext{
"Corresponding author: rector@undip.ac.id
} 


\section{Waste issues at Universitas Diponegoro}

As a university with autonomy in 2017, UNDIP is required to develop faster, both in the field of education, research and public services. These developments provide increased programs and activities as well as the involvement of various parties. So there is a significant increase in activity within the campus of UNDIP. The consequences of this increased activity include increased waste.

Problems resulting from increased waste production and pollutants are the main problems associated with environmental issues [3]. Especially for campus UNDIP, then this is closely related to personal activities, office, as well as laboratories or university hospitals. The resulting waste is not only in solid form, but also the liquid that should be treated differently. Especially for waste from laboratories and hospitals that are very hazardous have become toxic pollutants. These kind of wastes require special treatment for handling, because it is not only harmful to the environment but also to humans. While the air pollutants inside the campus, mainly derived from the use of cars and motorcycles on campus by students and university employees. For air waste is also required a special policy for handling. UNDIP's campus.

\section{Waste management practices}

"Understanding waste" is a major aspect to be undertaken before determining a policy for its handling [4]. Understanding means we know where the waste comes from, why waste appears, what are the properties of the waste, what is the effect of waste both on environment and human, and so on. Given the enormous waste generated by humanity and its impact, the environmental management has become an international issue, not only politically and economically, but also educationally related.

UNDIP campus with thousands of people consists of student, lecturer and employee, and other supporting component, has a potency to generate waste from their activities. One of it is solid waste or garbage / rubbish which is a focus of treatment beside other environment fields such as water, drinking / clean water, wastewater, drainage, green space, and energy. For energy usage, UNDIP has the policy to optimized energy availability [5]. In the framework of waste management and environment, UNDIP undertakes various steps and policies in managing the environment, including related to the handling of waste. Some of these programs include:

\section{Solid waste management}

TPST (Integrated Waste Management Site or integrated solid waste treatment plant) is located inside the campus that plays a role in managing solid waste generated within the campus of UNDIP. This TPST Management Agency is responsible for collecting, managing, and treating solid waste from 14 faculties and other activity buildings as a student, academic and general administration. Before this TPST was formed, the street sweeper in UNDIP always burned the garbage, but this has not happened again.

The quantities of solid waste in UNDIP campus approximately $50 \mathrm{~m}^{3} /$ day contributed up to $1 \%$ of solid waste generated in Semarang City, whereas the qualities of it are mixed compositions of organic, non-organic and residue. However, given the current capacity, not all solid waste can be handled by TSPT. UNDIP in cooperation with the city of Semarang in handling the remaining waste around $30 \%$ in the waste management of the city of Semarang.

There are several kinds of supporting infrastructures such as worker/employee, collector vehicle or it known as "Roda Tiga" or three wheels, and waste bin (green as organic waste and yellow as an-organic waste). TPST as a place of solid waste management adopting $3 \mathrm{R}$ program of Indonesia's national solid waste management and one of the waste management infrastructure is used as treatment and separation of solid waste compositions and characteristics in UNDIP Campus. TPST received the mixed solid waste or heterogeneous waste, but it is separated at TPST. TPST separated organic, nonorganic, and residue into specific compositions such as organic consist of organic compostable and non-compostable, nonorganic consist of recovery and non-recovery, and residue is stated as non-recovery and inert waste.

\section{Organic and Non-Organic Waste}

Given that the resulting solid waste is heterogeneous waste, it is first separated between organic and nonorganic waste. This separation is an important step in solid waste management $[6,7]$. This separation was carried out by the UNDIP waste management team at the faculty and university level. Until now, the composition of waste produced by UNDIP consist of 55\% organic, $40 \%$ an-organic, and 5\% residue. Compostable organic waste is approximately $40 \%$ of organic waste consisting of food waste and leaves litter, $20 \%$ of nonorganic waste consist of plastic waste, and $20 \%$ of nonorganic waste consist of paper, cloth, wood, rubber, glass, metal, and hazardous waste.

\section{Hazardous waste management}

Various types of waste are produced by laboratories and hospitals have hazardous and toxic properties [8, 9]. Such waste is very dangerous for the environment, humans and other living creatures. Hazardous waste and toxic such as this have the requirements and procedures to manage them $[10,11]$, therefore UNDIP cooperates with Semarang city government so that this waste can be treated exclusively in accordance with the instructions of this waste processing.

\section{Parks and other facilities}

In the environmental management process at the UNDIP campus in Tembalang, Semarang, we set up some important support facilities. This facility greatly influences the success of environmental management and is able to create a good environmental atmosphere 
for educational process in UNDIP. In addition to TPST, some of the main support facilities are:

a.Rare Plant Corner.

Located near UNDIP integrated laboratory, within this park there are some rare plants that are intentionally planted to maintain its existence. In general, this rare plant originated from Indonesia and is the result of cooperation with the Environment Agency of Central Java Province. More than 30 species of rare plants available in this park.This park is planned to be more developed, so that more rare plants are awake its existence.

b.Campus Forest

The campus forest in UNDIP is a natural forest that has always existed and developed with new plants through tree planting program. This forest is located on the road to the education reservoir. In addition to being useful as a green space in maintaining air quality on campus, this forest is also beneficial for lecturers and students especially in plant identification and forest management.

c.Taman Rusa

Deer Park was established in collaboration with BKSDA (Natural Resources Conservation Center). The type of deer that exists is the protected deer (Timor Deer, Cervus timorensis) and is now successfully developed successfully. Deer Park is located in Faculty of Animal Science and Agriculture and has been operated since 2014 started with 7 deer's. To date there are more than 20 Timor Deer in the park.

d.Educational Reservoir

The educational reservoir located on the campus of UNDIP was built in cooperation with the Ministry of Public Works of the Republic of Indonesia. This reservoir plays not only as a reservoir of water from the river that flows in the middle of the UNDIP campus, but also beneficial for lecturers and students in studying the management of reservoirs and their utilization. Even now the location of the reservoir is a place for visits to local attractions, especially on the weekend.

e.Agrotechnopark

Agrotechnopark is located at Faculty of Animal Science and Agriculture and has been operated since in the middle of 2016. In this agrotechnopark other than chicken coop with the Close House system, there are also agricultural crops. Technopark is very useful for lecturers and students, especially in managing various activities related to the field of animal science and the surrounding environment.

f.Parking Lot

UNDIP also provides a parking lot that aims to regulate the car park, so it will further minimize the effect of exhaust gas. Currently under construction of a new parking lot to accommodate cars that do not have a parking space. Based on calculations that we have done, it turns out the carbon dioxide produced by the vehicle UNDIP during peak hours, still much lower than the ability of all the trees in each unit to absorb the carbon dioxide. So far, the air at UNDIP campus is still very clean and not polluted.

\section{Supporting activities}

a.Tree planting

Tree planting program has been widely conducted worldwide with different opinions [12]. At UNDIP, tree planting is a routine program that continues to be held especially at the university level. Until now all the locations have been planted with trees of various types. One of the university's policies is that every new students must bring one tree, and the planting activities are regulated by UNDIP environmental managers..

b.Environmental related courses

To raise awareness of the importance of environmental management, almost all departments have courses related to the environment. For study programs such as Marine Sciences, Fisheries Science, Animal Husbandry, Agriculture, Biology and so on, are dominated by courses related to the environment. As for other departments also provided courses related to the environment..

c.Greenmetric WUR

UNDIP has been very actively involved in the ranking related to environmental management UIGreenmetrics World University Ranking. We consider this type of ranking is very important to follow, because it will give an overview of the advantages and disadvantages of UNDIP in environmental management. This will make it easier for us to develop new policies to improve the management system.

Waste management on campus UNDIP is closely related to environmental management in general and we are very committed to this. This is done in order to continually improve environmental conditions in UNDIP [1]. We believe that the desire to be sustainable university with a clean, healthy, and convenient campus for all can be achieved and will improve the performance of Diponegoro University.

\section{References}

1. Utama, Y.J., Purwanto, and Ambariyanto. Developing Environmentally Friendly Campus at Diponegoro University. Advanced Science Letters, 23(3): 2584-2585 (2017)

2. Ambariyanto, A., Utama, Y. J., Darsono, D., Setyiono, B., Zainuri, M., and Noor, R. Supporting Indonesian Government Maritime Policy, Through Diponegoro University Main Scientific Interest. Advanced Science Letters, 23(10): 10061-10063. (2017)

3. Zurbrugg, C., Urban solid waste management in low-income countries of Asia: How to cope with the garbage crisis. Presented for: Scientific Committee on Problems of the Environment (SCOPE) Urban Solid Waste Management Review Session, Durban, South Africa, pp.1-13. (2002) 
4. Palmer, J. A. Environmental thinking in the early years: Understanding and misunderstanding of concepts related to waste management. Environmental Education Research, 1(1), 35-45. (1995)

5. Ambariyanto, A., Utama, Y. J. and Purwanto. Managing Campus Energy: Compromising between Rapid Needs and Environmental Requirement. In E3S Web of Conferences. 31: 01003) (2018)

6. Artiningsih, N.K.A., Peran serta masyarakat dalam pengelolaan sampah rumah tangga (Studi kasus di Sampangan dan Jomblang, Kota Semarang). Thesis, Program Pascasarjana Universitas Diponegoro.110 pp. (2008)

7. Riswan, R., Sunoko, H.R. and Hadiyarto, A., 2011. Pengelolaan sampah rumah tangga di Kecamatan Daha Selatan. Jurnal Ilmu Lingkungan, 9(1), pp.3138. (2011)

8. Marinković, N., Vitale, K., Holcer, N. J., Džakula, A., and Pavić, T. Management of hazardous medical waste in Croatia. Waste management, 28(6): 10491056. (2008)

9. Wilson, J. L. Laboratory investigation of residual liquid organics from spills, leaks, and the disposal of hazardous wastes in groundwater. Robert S. Kerr Environmental Research Laboratory, Office of Research and Development, US Environmental Protection Agency. (1990)

10. Paramita, N., Evaluasi Pengelolaan Sampah Rumah Sakit Pusat Angkatan Darat Gatot Soebroto. Jurnal Presipitasi, 2(1), pp.51-55. (2007)

11. Harjanto, N.T., Suliyanto, S. and Ismojowati, E.S., Manajemen Bahan Kimia Berbahaya Dan Beracun Sebagai Upaya Keselamatan Dan Kesehatan Kerja Serta Perlindungan Lingkungan. PIN Pengelolaan Instalasi Nuklir, 8 (IV): 54-67. (2013)

12. Summit, J., and Sommer, R. Urban tree-planting programs-A model for encouraging environmentally protective behavior. Atmospheric Environment, 32(1): 1-5. (1998) 